\title{
Poly(amido amine)s as Gene Delivery Vectors: Effects of Quaternary Nicotinamide Moieties in the Side Chains
}

\author{
Miguel A. Mateos-Timoneda, ${ }^{[a]}$ Martin C. Lok, ${ }^{[b]}$ Wim E. Hennink, ${ }^{[b]}$ Jan Feijen, ${ }^{[a]}$ and \\ Johan F. J. Engbersen ${ }^{*[a]}$
}

Dedicated to Professor David N. Reinhoudt on the occasion of his 65th birthday

\begin{abstract}
To evaluate the effect of quaternary nicotinamide pendant groups on gene delivery properties, a series of poly(amido amine) (co)polymers were synthesized by Michael addition polymerization of $N, N^{\prime}$-cystaminebisacrylamide with variable ratios of 1 (4-aminobutyl)-3-carbamoylpyridinium (Nic-BuNH ${ }_{2}$, and tertbutyl-4-aminobutyl carbamate (BocNH-BuNH $\mathrm{H}_{2}$ ), yielding poly (amido amine)s (NicX-NHBoc) with $X=0,10,30$, and $50 \%$ of quaternary nicotinamide groups in the polymer side chains. Deprotection of the pendant Boc-NH groups afforded an analogous series of polymers ( $\mathrm{NiCX}-\mathrm{NH}_{2}$ ) with higher charge density (due to the presence of protonated primary amino groups in the side chains) and subsequent acetylation yielded a series of polymers (NicXNHAc) of lower hydrophobicity than the Boc-protected polymers. The polymers with the Boc-protected or the acetylated amino groups showed high buffer capacity in the range pH5.1-7.4, which is a property that can contribute to endosomal escape of polyplexes. The presence of quaternary nicotinamide groups has
\end{abstract}

distinct beneficial effects on the gene vector properties of these polymers. The polymers containing $\geq 30 \%$ of quaternary nicotinamide groups in their side chains condense DNA into small, nanosized particles $(\leq 200 \mathrm{~nm})$ with positive surface charge $(\geq+$ $15 \mathrm{mV}$ ). Fluorescence experiments using ethidium bromide as a competitor showed that the quaternary nicotinamide groups intercalate with DNA, contributing to a more intimate polymerDNA binding and shielding. Polyplexes of nicotinamide-functionalized poly(amido amine)s NiCX-NHBoc and NiCX-NHAC, formed at 12/1 polymerDNA mass ratio, efficiently transfect COS-7 cells with efficacies up to four times higher than that of PEI (Exgen 500), and with essentially absence of cytotoxicity. Nic $\mathrm{X}-\mathrm{NH}_{2}$ polymers, possessing protonated primary amino groups in their side chains, have a higher cytotoxicity profile under these conditions, but at lower 3/1 polymer-DNA mass ratio also these polymers are capable of efficient transfection, while retaining full cell viability.

\section{Introduction}

The development of safe and efficient vectors for the delivery of genetic material into cells is one of the main hurdles for the progress of gene therapy as a cure for several diseases, such as cystic fibrosis and cancer. ${ }^{[1-4]}$ Although viral vectors can be employed for intracellular delivery of genetic material with high efficiency, these vectors are associated with inherent cytotoxicity, immunogenicity, and mutagenicity problems as well as having limitations in terms of the size and quantity of the inserted genetic materials. ${ }^{[5]}$ Therefore, nonviral vectors are emerging as an attractive alternative, ${ }^{[6,7]}$ because of their ease of production, stability, low immunogenicity and toxicity, and capacity to deliver larger genetic payloads. ${ }^{[8]}$ Among them, cationic polymers, such as polyethylenimine (PEI), poly-L-Lysine, and poly(amido amine)s dendrimers, ${ }^{[9-12]}$ have been reported as promising materials, as these cationic polymers are able to complex with DNA to nanosized particles (polyplexes), thereby protecting DNA from nucleases and promoting cellular uptake by (mainly) endocytosis. ${ }^{[13]}$

Nevertheless, these cationic polymers are not able to overcome all the different barriers for the successful delivery of genetic material inside cells, such as efficient selective cellular uptake and endosomal escape of polyplexes, vector unpacking and cytoplasmic trafficking, and nuclear internalization of free DNA. ${ }^{[14,15]}$ Especially unpacking of the genetic material from the polymer and the cellular trafficking of DNA were revealed to be the most limiting factors for successful gene transfer in vitro, ${ }^{[16]}$ besides the obvious requirement that the cytotoxicity of the applied polymers should be low. The latter point has been addressed by using biodegradable polymers, possessing hydrolytically cleavable ester groups or bioreducible disulfide linkages in their backbone. ${ }^{[17-20]}$ Moreover, the cleavage of these groups in the cellular interior could beneficially contribute to the release of the genetic payload, leading to the development of polymeric vectors which display similar or higher transfection efficiency but lower cytotoxicity than their nonde-

\footnotetext{
[a] Dr. M. A. Mateos-Timoneda, Prof. J. Feijen, Prof. J. F. J. Engbersen Department of Biomedical Chemistry and Department of Polymer Chemistry and Biomaterials Institute for Biomedical Technology (BMTI) Faculty of Science and Technology University of Twente P.O. Box 217, 7500 AE Enschede (The Netherlands) Fax: $(+31) 53-489-2155$ E-mail:j.f.j.engbersen@tnw.utwente.nl

[b] M. C. Lok, Prof. W. E. Hennink Department of Pharmaceutics Utrecht Institute for Pharmaceutical Science (UIPS) Utrecht University

P.O. Box 80082, 3508 TB, Utrecht (The Netherlands)
} 
gradable counterparts. However, it is conceivable that for efficient transfection also the degree of protection and the stage at which DNA is released from its protective polymeric environment is critical, as insufficient protection and/or early release can lead to degradation of most of the internalized DNA because of the presence of DNAses in the cytoplasm.

Previous studies of Ferruti et al. ${ }^{[21,22]}$ have shown that poly(amido amine)s are a versatile class of polymers that have promising properties for gene and drug delivery as these peptidomimetic polymers are biodegradable and many of them show essentially no or only low cytotoxicity. Recently, we have found that the presence of disulfide linkages in the main chain of the poly(amido amine)s enhances the transfection efficiency, most probably by promotion of the release of the genetic material in the intracellular space by reductive cleavage of the disulfide bonds. ${ }^{[23-27]}$ In this paper we report on the synthesis and gene delivery properties of a series of novel poly(amido amine)s that contain both disulfide linkages in their backbone as well as different amounts of quaternary nicotinamide moieties in their side chains (see Scheme 2). It was hypothesized that presence of the positively charged, planar quaternary nicotinamide moieties in the polymer could have beneficial effects on the polymer-DNA interactions not only by electrostatic interaction but also by intercalation with DNA, resulting in increased condensation and protective shielding of the DNA due to the proximate intercalate binding with the polymer. Quaternary nicotinamide groups were selected as pendant groups in these polymers above well-known intercalating groups like acridinium because of the expected biocompatibility of the natural occurring quaternary nicotinamide group in $\mathrm{NAD}^{+}$.

\section{Results and Discussion}

\section{Monomer synthesis}

The quaternized nicotinamide monomer, 1-(4-aminobutyl)-3-carbamoylpyridinium (Nic-BuNH${ }_{2}$ ), was synthesized by reaction of tert-butyl-4-aminobutylcarbamate $\left(\mathrm{BocNH}-\mathrm{BuNH}_{2}\right)$ with the 3-carbamoyl-1-(2,4-dinitrophenyl)pyridinium ion 1 . In this reaction the nucleophilic amine group of $\mathrm{Nic}-\mathrm{BuNH}_{2}$ adds to the 6position of the nicotinamide ring of $\mathbf{1}$, followed by a ring opening-ring closure reaction with the expulsion of the 2,4-dinitroaniline group ${ }^{[28]}$ and formation of the Boc-protected product Nic-BuNHBoc in $46 \%$ yield. Subsequent acid-catalyzed removal of the Boc protective group gives the desired monomer, Nic$\mathrm{BuNH}_{2}$ in quantitative yield (Scheme 1).

\section{Synthesis and characterization of poly(amido amine) homopolymers and copolymers}

Poly(amido amine)s ((PAA)s) with 0, 10, 30, and $50 \%$ of the side chains provided with quaternary nicotinamide moieties were synthesized by Michael addition and $50 \%)$. polymerization of bisacrylamide $\mathrm{CBA}$ with the appropriate ratio of Nic-BuNH ${ }_{2} /$ BocNH-BuNH $_{2}$ (Scheme 2).

The polymerizations were carried out with equimolar monomeric ratios of primary amine and bisacrylamide. During the polymerization a gradual increase in viscosity was observed. In all cases gelation did not occur. To consume any unreacted acrylamide groups after polymerization $15 \mathrm{~mol} \%$ excess BocNH$\mathrm{BuNH}_{2}$ was added to the reaction mixture. The polymers, obtained in $\sim 30 \%$ yield, were isolated by exhaustive ultrafiltration, followed by freeze-drying. The resulting PAA homo- and copolymers have a good solubility in water. The ${ }^{1} \mathrm{H}$ NMR spectra of these polymers were in full accordance with the expected structures, implying that the obtained composition ratio is equal to the applied feed ratio of the different monomers (Figure 1). No signals were observed between 5 and 7 ppm, indicating that acryl groups are essentially absent $(\leq 2 \%)$ and the PAAs are end-capped with amino groups. A combination of small angle light scattering, high angle light scattering, and refractive index measurements showed that the weight-aver-

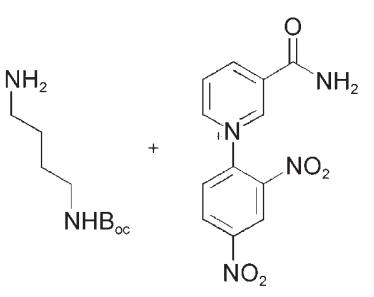

$\mathrm{BocNH}-\mathrm{BuNH}_{2}$ 1
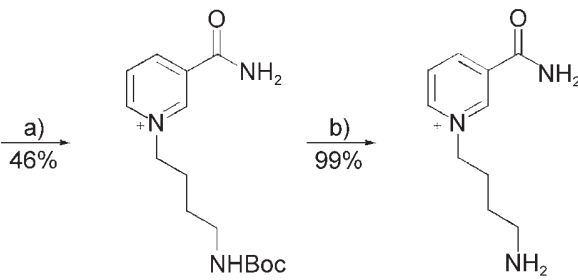

Nic-BuNHBoc

$\mathrm{Nic}-\mathrm{BuNH}_{2}$

Scheme 1. Synthesis of monomer Nic-BuNH$H_{2}$. Reagents and conditions: a) $\mathrm{MeOH}$, reflux, $12 \mathrm{~h}$; b) TFA, $\mathrm{MeOH}, 8 \mathrm{~h}$.

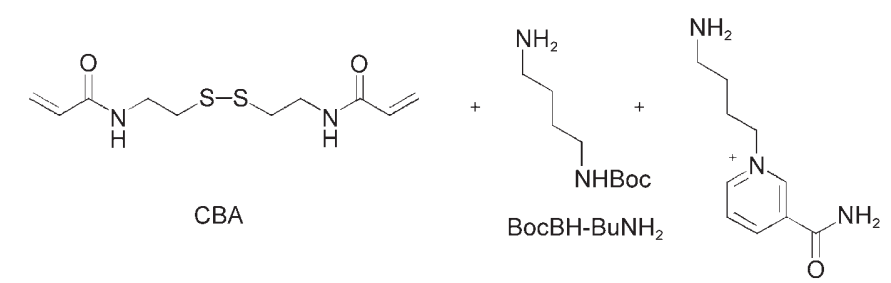

Nic-BuNH

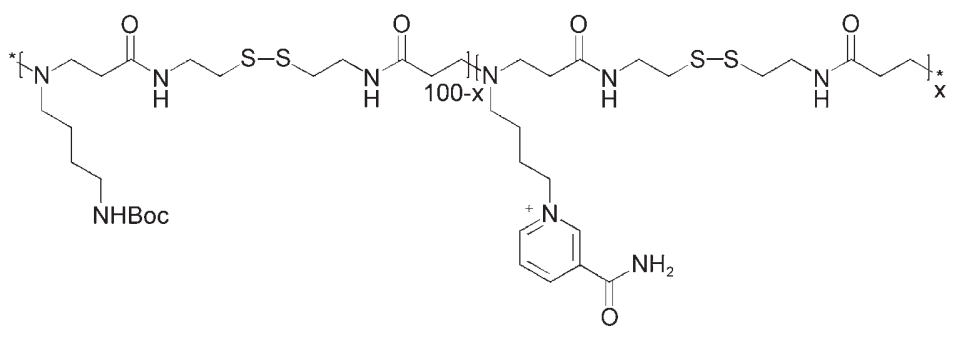

$\mathrm{p}(\mathrm{Nic} X-\mathrm{NHBoc})$

Scheme 2. Synthesis of poly(amido amine)s $p(N i c X-N H B o c)$, where $X$ represents the percentage of side chains containing the quaternized nicotinamide moiety $(X=0,10,30$, 
age molecular weight $\left(M_{\mathrm{w}}\right)$ of the PAAs ranges from 6300 to $26000 \mathrm{~g} \mathrm{~mol}^{-1}$.

Acid-based deprotection of the Boc-protected amino groups of the side chain of the polymers yielded polymers with various amounts of primary amino groups and quaternary nicotinamide groups in the side chains (Scheme 3). Acetylation of the primary amino groups further allows the evaluation of effects of the presence of (protonated) primary amino groups compared to quaternary nicotinamide groups as well as effects of changes in hydrophobicity ${ }^{[29]}$ of the side chain (acetylated versus Boc-protected amino groups). The removal of the Boc protective groups and the subsequent acetylation of the resulting free amino groups could be followed by the changes of the appropriate signals in the ${ }^{1} \mathrm{H}$ NMR spectra. The disappearance of the signal at $\delta=1.5 \mathrm{ppm}$ after addition of TFA to the $\mathrm{p}(\mathrm{Nic} X$ NHBoc) polymers clearly shows that the Boc group was removed from the protected amino groups. Similarly, the appearance of a signal at $\delta=2.3 \mathrm{ppm}$ upon addition of acetic anhydride to the $\mathrm{p}\left(\mathrm{Nic} X-\mathrm{NH}_{2}\right)$ polymers shows that acetylation of the free amino groups in the polymers has occurred.

As has been pointed out before, endosomal escape is one of the main barriers for efficient gene delivery. The so-called proton sponge hypothesis has been postulated to explain endosomal disruption by cationic polymers with ionizable amine groups, such as B-pEl. ${ }^{[30]}$ This theory assumes that in the endosome, basic amine groups in the polymer become protonated when the $\mathrm{pH}$ drops from $\mathrm{pH} 7.4$ to approximately 5 , resulting in an influx of chloride ions and water into the endosomal compartment, leading to swelling and, eventually, osmotic lysis. ${ }^{[31]}$ From our previous studies we have observed that the buffer capacity of the poly(amido amine)s, defined as the percentage of amino groups that becomes protonated in the $\mathrm{pH}$ range 7.4 to 5.1 , may be a relevant parameter in the overall transfection process. ${ }^{[24-26]}$ It is important to note that the buffer capacity as defined for this $\mathrm{pH}$ range does not take into account the amount of nitrogen groups that are already protonated at $\mathrm{pH} 7.4$ or higher. Moreover, besides osmotic effects conformational changes in the polymer, due to an increased degree of protonation of the polymer backbone, may play a role in the endosomal escape process. The buffer capacity of the Boc-protected

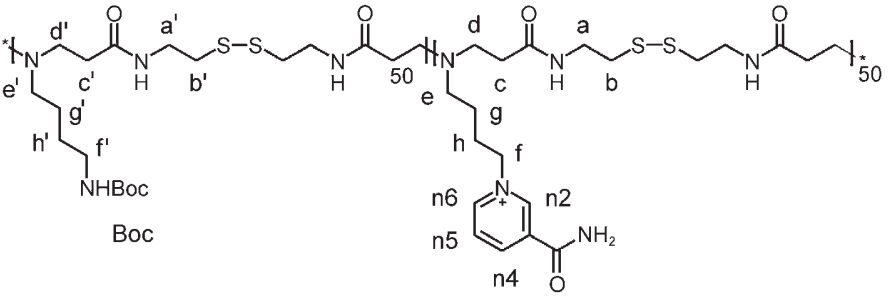

n4 $\prod_{\mathrm{O}}$

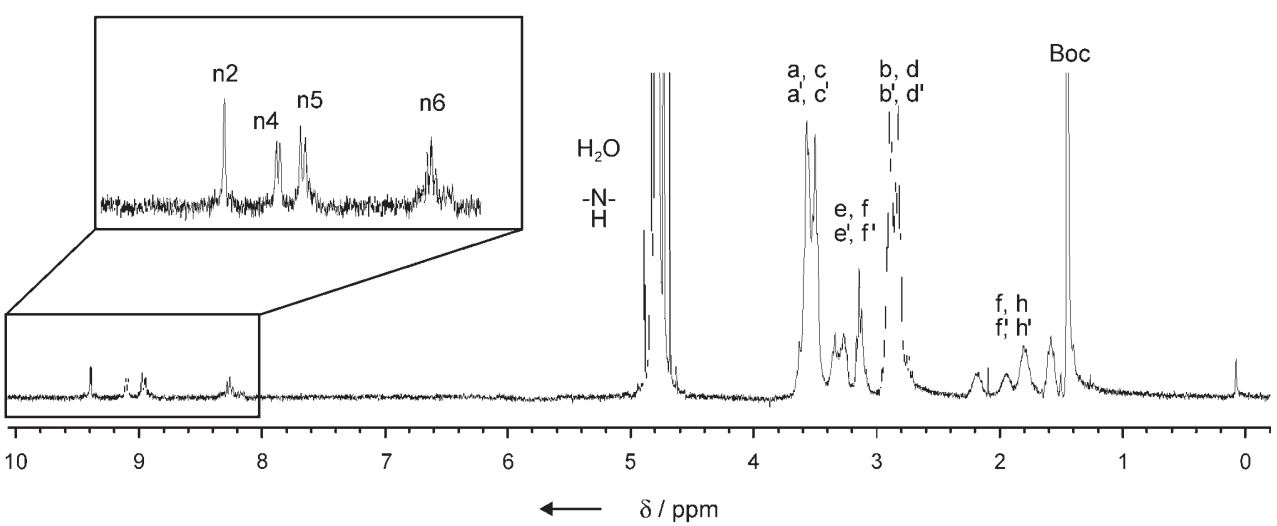

$\longleftarrow \quad \delta / \mathrm{ppm}$

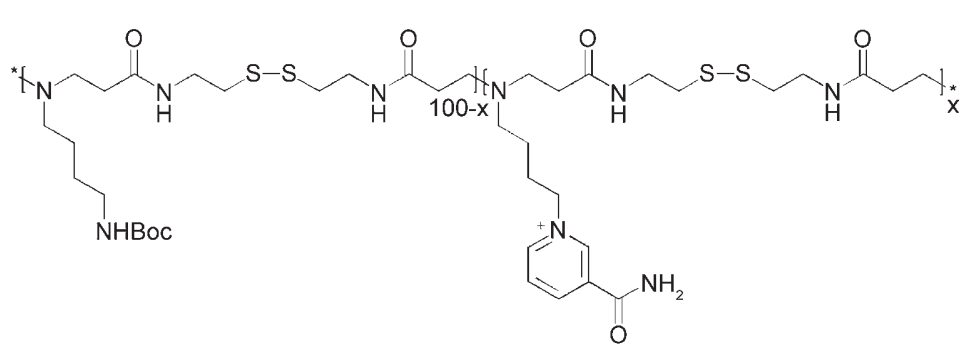

$\mathrm{p}(\mathrm{Nic} X-\mathrm{NHBoc})$

a)

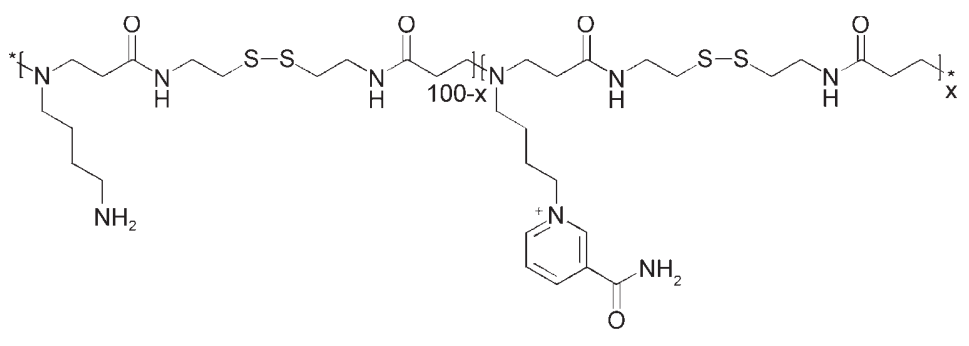

$\mathrm{p}\left(\mathrm{Nic} X-\mathrm{NH}_{2}\right)$

b)

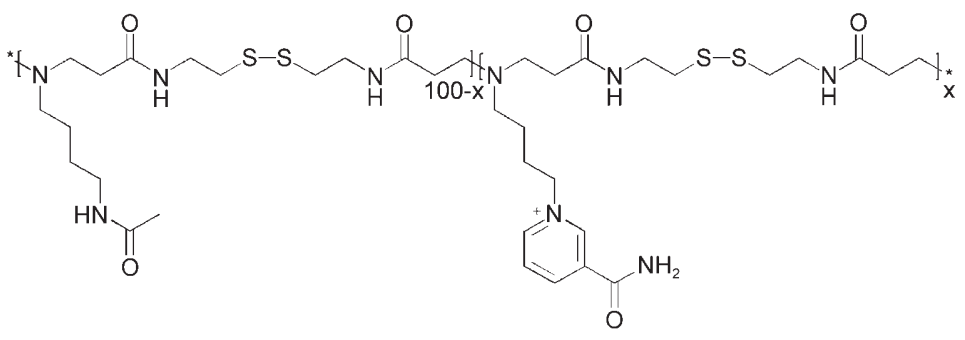

$\mathrm{p}(\mathrm{Nic} X-\mathrm{NHAC})$

Scheme 3. Deprotection and acetylation of PAAs. Reagents and conditions: a) TFA, $\mathrm{MeOH}, 6 \mathrm{~h}, \mathrm{~b}) \mathrm{Ac}_{2} \mathrm{O}, \mathrm{MeOH}, 60^{\circ} \mathrm{C}, 6 \mathrm{~h}$. 
$\mathrm{p}(\mathrm{Nic} X-\mathrm{NHBoc})$ polymers, together with $\mathrm{PEI}$ as a reference, is illustrated in the acid-base titration curves depicted in Figure 2. The relatively flat slope in the $\mathrm{pH}$ range 5.1-7.4 indicates the

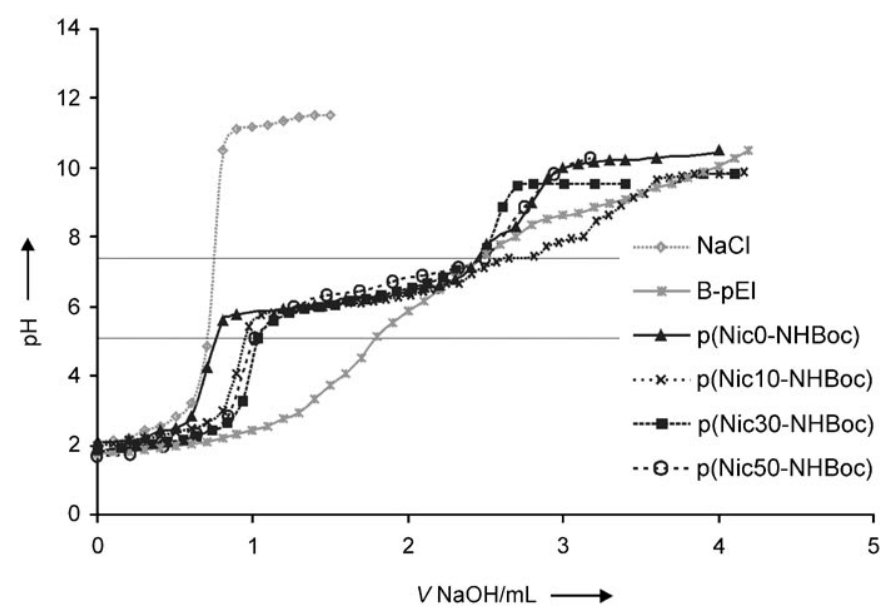

Figure 2. Titration curves obtained by titrating aqueous solutions $(\mathrm{pH} 2$, adjusted with $1 \mathrm{M} \mathrm{HCl}$ ) of poly(amido amine) ( $25 \mathrm{~mm}$ amino nitrogen atoms) in $10 \mathrm{~mL}$ of $150 \mathrm{~mm}$ aqueous $\mathrm{NaCl}$ with $0.1 \mathrm{M} \mathrm{NaOH}$.

high buffer capacity (68\%-75\%) of the PAA polymers in this region, which is significantly higher than that of $25 \mathrm{k}$ branched PEI (17\%) (see also the data in Table 1).

Obviously, the buffer capacity of the polymers with free amino groups in the side chain is much lower than that of the polymers with the Boc-protected amino groups, reflecting the higher degree of protonation of the former polymers at $\mathrm{pH}$ 7.4. For example, comparing the polymers containing $10 \%$ of nicotinamide moieties, the buffer capacity decreases from $70 \%$ for $\mathrm{p}(\mathrm{Nic} 10-\mathrm{NHBoc})$ to $33 \%$ for $\mathrm{p}\left(\mathrm{Nic} 10-\mathrm{NH}_{2}\right)$. Acetylation of the free amino groups results in a decreased amount of protonated amino groups at $\mathrm{pH} 7.4$, similar to the Boc-protected polymers, and therefore an increase of the buffer capacity in the $\mathrm{pH}$ range $7.4-5.1$ is observed. Polymer $\mathrm{p}$ (Nic10-NHAc) shows a buffer capacity of $57 \%$, which is much higher than that of $\mathrm{p}\left(\mathrm{Nic} 10-\mathrm{NH}_{2}\right)$, but lower than that of $\mathrm{p}$ (Nic10-NHBoc). As $\mathrm{p}$ (Nic10-NHAC) and $\mathrm{p}$ (Nic10NHBoc) have the same amount of basic nitrogens, the difference may be explained by the stronger hydrophobic environment of $\mathrm{p}$ (Nic10-NHBoc), giving rise to a lower degree of protonation of this polymer at $\mathrm{pH}$ 7.4.

\begin{tabular}{|c|c|c|c|}
\hline $\begin{array}{l}\text { Polymer } \\
\% \text { Nicotinamide }\end{array}$ & $\mathrm{p}(\mathrm{Nic} X-\mathrm{NHBoc})$ & $\mathrm{p}\left(\mathrm{NicX}-\mathrm{NH}_{2}\right)$ & $\mathrm{p}(\mathrm{Nic} X-\mathrm{NHAc})$ \\
\hline 0 & 67 & 29 & 54 \\
\hline 10 & 70 & 32 & 57 \\
\hline 30 & 72 & 36 & 61 \\
\hline 50 & 75 & $-^{[b]}$ & $-^{[b]}$ \\
\hline \multicolumn{4}{|c|}{$\begin{array}{l}\text { [a] Buffer capacity (\% change in protonation) between } \mathrm{pH} 7.4 \text { and } 5.1 \text { in } \\
150 \mathrm{~mm} \mathrm{NaCl} \text {. [b] Not determined. }\end{array}$} \\
\hline
\end{tabular}

\section{Characterization of polymer/DNA complexes}

A requisite for their function as a gene delivery vehicle is that the cationic polymers are able to condense DNA into nanosized particles. ${ }^{[32,33]}$ The particle size and zeta-potential of polyplexes based on the different polymers at a polymer/DNA mass ratio 12/1 are shown in Figure 3.

Except for the Boc-protected polymers without or with only $10 \%$ nicotinamide groups ( $\mathrm{p}(\mathrm{Nic}-\mathrm{NHBoc})$ and $\mathrm{p}$ (Nic10NHBoc)), all other polymers are able to condense DNA into nanosized particles $\leq 200 \mathrm{~nm}$. It is clear that the presence of increasing amounts of quaternary nicotinamide moieties at the side chain leads to a decrease of the particle size of the polyplexes, indicating a positive influence on the DNA condensation by these groups. The importance of the hydrophobicity of the side groups on the condensation properties of these polymers is clearly reflected in the differences in size and zeta potential of the polyplexes formed from $p(\mathrm{Nic} X-\mathrm{NHBoc})$ and $\mathrm{p}(\mathrm{Nic} X-\mathrm{NHAc})$. The more hydrophobic side chains of $\mathrm{p}(\mathrm{Nic} X-$ $\mathrm{NHBoc}$ ) are expelled from the aqueous environment and induce a higher polymer density in the interior of the polyplex particle, thereby exposing DNA more strongly to the surface.

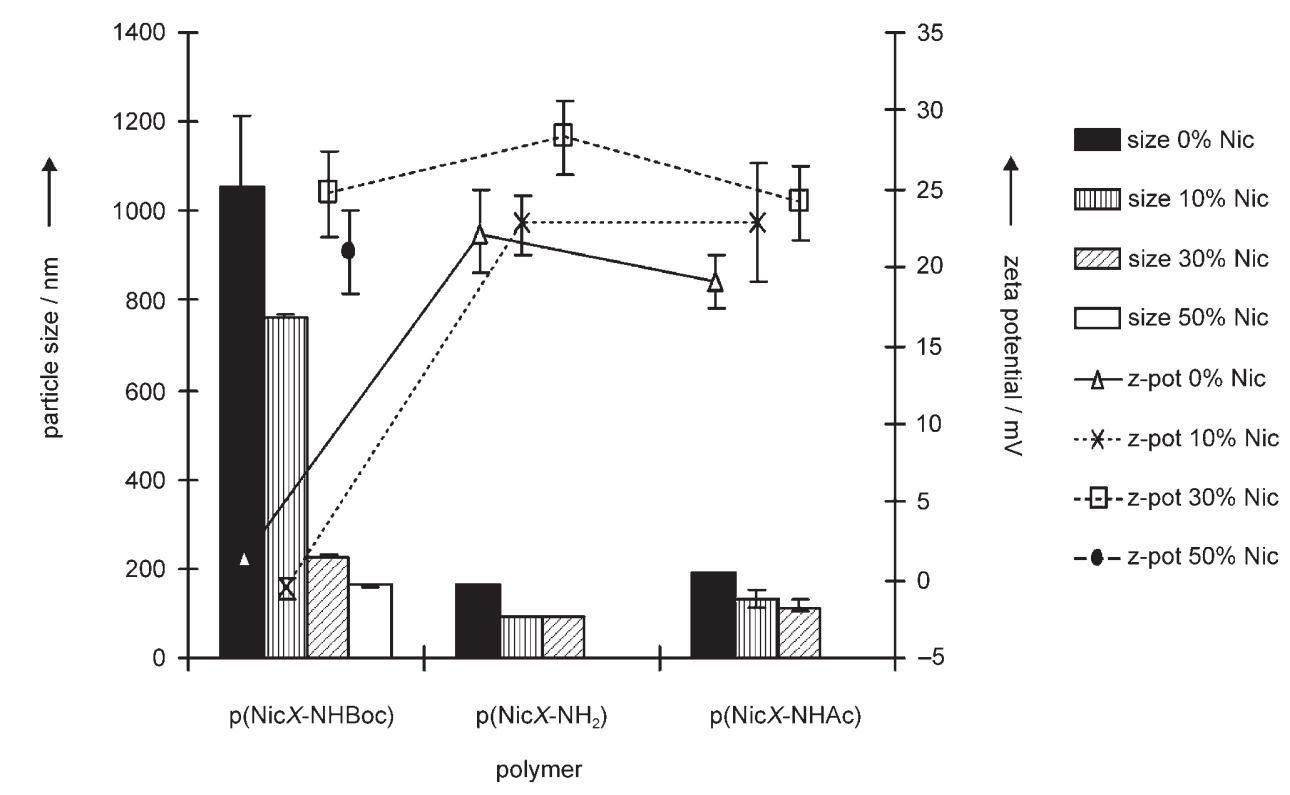

Figure 3. Average particle size (solid bars) and zeta potential (connecting lines) of polyplexes of PAAs at polymer/ DNA mass ratios 12/1 (20 mm HEPES buffer, pH 7.4, 5 wt \% glucose). 
This is reflected in the low zeta potential of polyplexes from $\mathrm{p}$ (Nic0-NHBoc) and $\mathrm{p}(\mathrm{Nic} 10-\mathrm{NHBoc})$, containing the highest amount of Boc groups. Moreover, such assembling with low surface charge allows further growth to large particles. For polymers $\mathrm{p}\left(\mathrm{Nic} X-\mathrm{NH}_{2}\right)$, the small size of the polyplexes $(\sim 90 \mathrm{~nm}$ for $\mathrm{p}\left(\mathrm{Nic} 10-\mathrm{NH}_{2}\right)$ and $\left.\mathrm{p}\left(\mathrm{Nic} 30-\mathrm{NH}_{2}\right)\right)$ can be attributed to the higher net positive charge of these polymers, due to the presence of protonated primary amino groups in the side chain, and the positive contribution of intercalation and electrostatic interaction of the quaternary nicotinamide groups with DNA.

\section{Influence of the quaternary nicotinamide moieties in DNA binding and shielding}

To investigate the effect of the quaternary nicotinamide moieties in the DNA binding and shielding capacity, the degree of intercalation of ethidium bromide with accessible DNA and the competitive displacement of DNA by heparin were measured by fluorescence. ${ }^{[34]}$ Figure 4 shows the change in ethidium bromide fluorescence upon addition of heparin to polyplexes of the different copolymers. The addition of heparin to the polyplexes results in an increase of the fluorescence signal of ethidium bromide due to an increased accessibility of DNA for intercalation with the ethidium ion. From Figure 4 it is clear that the increase of fluorescence is much lower for polyplexes formed with polymers possessing the higher ratios of quaternary nicotinamide moieties, indicating that the presence of the nicotinamide groups leads to an extra stabilization of the polyplexes relative to the heparin-polymer interaction. Similar results were obtained with $\mathrm{pNic} 30-\mathrm{NH}_{2}$ polyplexes, supporting the assumption that specific interaction between the quaternary nicotinamide groups and DNA is responsible for the extra stabilizing effect of he polyplexes.

The intercalation capability of quaternary nicotinamide groups with DNA was clearly illustrated by the addition of the low-molecular mass model compound Nic-BuNHBoc to a solution of ethidium bromide and DNA (Nic-BuNHBoc/DNA 48/1 mass ratio). This resulted in a distinct decrease of the fluorescence signal, indicating the displacement of ethidium bromide by the quaternary nicotinamide group of Nic-BuNHBoc $\left(F_{r}=\right.$ $9.9 \%)$. Subsequent addition of heparin to the solution restored the fluorescence of ethidium bromide $\left(F_{\mathrm{r}}=13.2 \%\right)$ due to binding of the positively charged NicBuNHBoc to the negatively charged heparin.

\section{In vitro transfection efficiency and cell viability}

The transfection of polyplexes based on these poly(amido

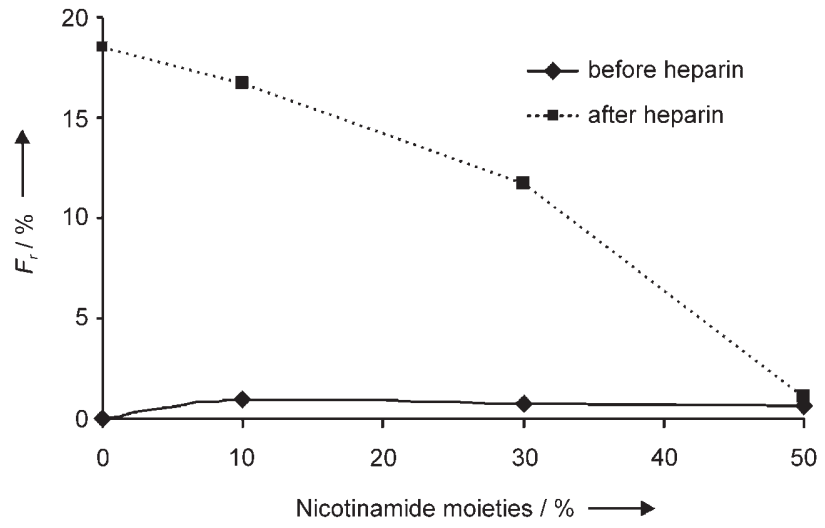

Figure 4. Ethidium bromide fluorescence (relative intensity) of polyplexes formed with $\mathrm{p}(\mathrm{NicX}-\mathrm{NHBoc})$ before ( )and after $(\boldsymbol{\square})$ the addition of 3 eq of heparin (respect to DNA). The polyplexes were formed at polymer/DNA ratio $48 / 1(w / w)$.

amine)s was studied in vitro by using COS-7 cells and plasmid pCMV-LacZ as reporter gene, and their cell viabilities were evaluated by XTT assays. Figure 5 shows the transfection efficiencies and the cell viability of the polyplexes based on the PAA polymers at $12 / 1$ polymer/DNA mass ratio together with the reference polymer Exgen 500 (linear PEI) at its optimal N/P ratio $(5 / 1)$ in the absence of serum. ${ }^{[35]}$

For all three types of PAAs, the presence of quaternary nicotinamide moieties has a significant influence on the transfection efficiency. The beneficial effect of these moieties is most clearly present in the $\mathrm{p}(\mathrm{Nic} 30-\mathrm{NHBoc})$ and $\mathrm{p}(\mathrm{Nic} 30-\mathrm{NHAc})$ polymers, containing $30 \%$ of quaternary nicotinamide groups, with transfection efficiencies up to four times higher than that of Exgen500. Moreover, polymers of this composition display no cytotoxic effects. The low transfection efficiencies of $p$ (NicO$\mathrm{NHBoc}$ ) and $\mathrm{p}$ (Nic10-NHBoc) can be attributed to their low surface charge and large particle size (see Figure 3), whereas polyplexes of $\mathrm{p}\left(\mathrm{Nic} X-\mathrm{NH}_{2}\right)$ show appreciable cytotoxicity, probably

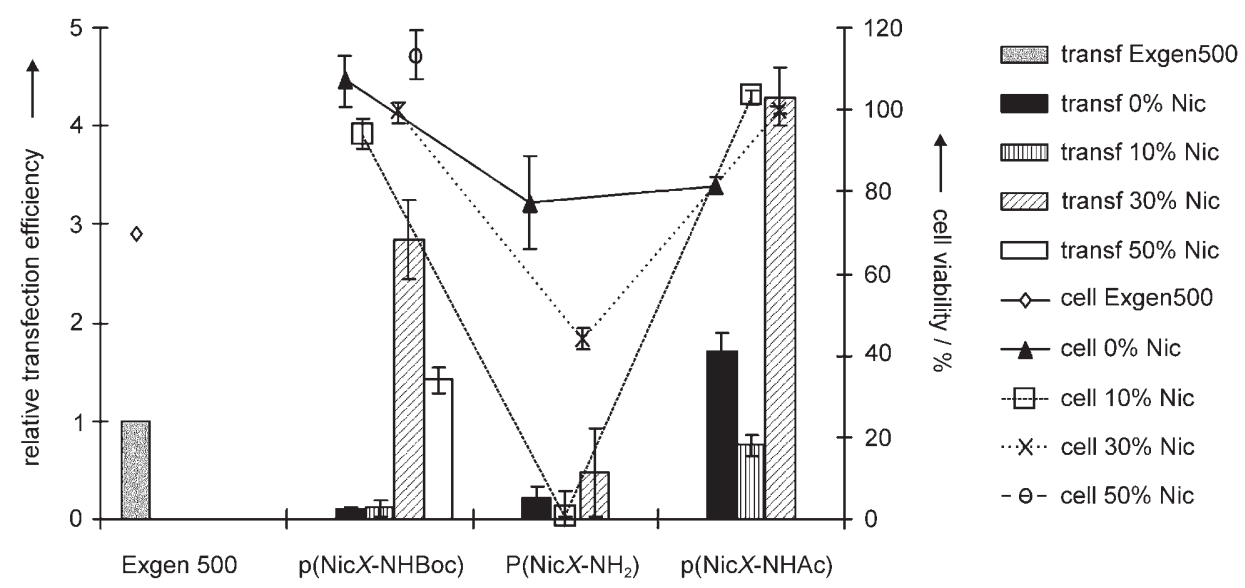

Figure 5. Transfection efficiencies (bars) and corresponding cell viabilities (connecting lines) of polyplexes of poly(amido amine)s containing different percentages of quaternary nicotinamide moieties in COS-7 cells at 12/1 polymer/DNA mass ratio in the absence of serum. The transfection efficiency of Exgen 500 polyplexes at their optimal $\mathrm{N} / \mathrm{P}$ ratio of $5 / 1$ was taken as reference (set at 1.0 ). Cell viability was determined by XTT assay. Data are expressed as mean values (standard deviations) of at least three experiments. 
due to the high positive charge density of these polymers with protonated amino groups in their side chain. However, when transfection experiments with $\mathrm{p}\left(\mathrm{Nic} X-\mathrm{NH}_{2}\right)$ were performed at a much lower 3/1 polymer/DNA mass ratio to reduce excess of positively charged polymer, cytotoxicity is essentially absent and much higher transfection efficiencies are observed, that is, for $\mathrm{p}\left(\mathrm{Nic} 30-\mathrm{NH}_{2}\right)$ the transfection is approximately 3.7 times higher than that of Exgen 500 (Figure 6).

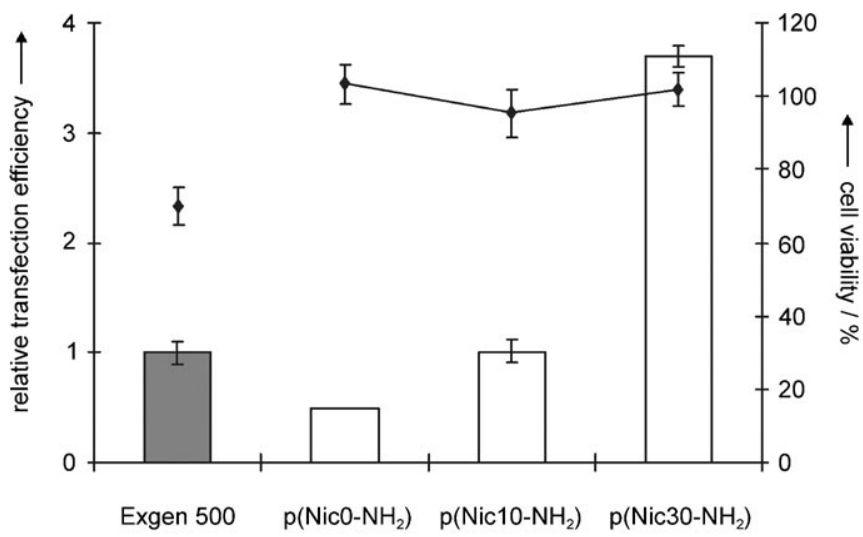

Figure 6. Transfection efficiencies (bars) and corresponding cell viabilities (connecting lines) of polyplexes of poly(amido amine)s $\mathrm{p}\left(\mathrm{NicX}-\mathrm{NH}_{2}\right)$ containing different percentages of quaternary nicotinamide moieties in COS-7 cells at 3/1 polymer/DNA mass ratio in the absence of serum. The transfection efficiency of Exgen 500 polyplexes at their optimal N/P ratio of 5/1 was taken as reference (set at 1.0). Cell viability was determined by XTT assay. Data are expressed as mean values (standard deviations) of at least three experiments.

As the presence of serum more closely resembles the in vivo environment, the influence of the presence of serum on the transfection was also evaluated. For polyplexes with positive surface charge it can be expected that the presence of serum will lead to a decrease of transfection efficiency due to adsorption of serum proteins and formation of aggregates. ${ }^{[36]}$ Generally, for the poly(amino amine)s used in this study a 2-3-fold decrease in transfection was observed compared to the serumfree medium. Similar to the serum-free medium, the polymers containing $30 \%$ of nicotinamide groups $\mathrm{p}(\mathrm{Nic} 30-\mathrm{NHBoc})$ and $\mathrm{p}(\mathrm{Nic} 30-\mathrm{NHAc})$ exhibit the highest transfection efficiency (still up to 1.6 times higher than that of the reference Exgen 500, which was always measured under standard serum-free conditions). As expected, the transfection of $\mathrm{p}\left(\mathrm{Nic} X-\mathrm{NH}_{2}\right)$ polymers is more strongly reduced by the presence of serum than that of the Boc-protected and acetylated polymers, caused by the interaction of the protonated amino groups with the serum proteins (Figure 7).

\section{Conclusions}

A synthetic route has been developed to introduce variable amounts of quaternary nicotinamide moieties in linear poly(amido amine)s by Michael addition polymerization. These novel polymers are able to condense DNA into nanosized particles

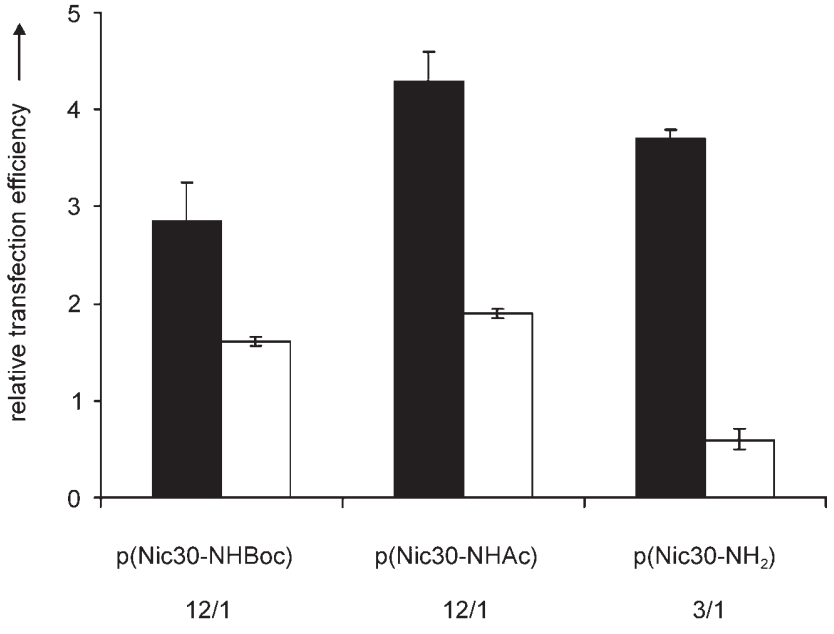

Figure 7. Transfection efficiencies in the absence (black bars) and the presence (white bars) of serum of polyplexes of poly(amido amine)s with the different side chains in COS-7 cells at their optimum polymer/DNA mass ratio. The serum-free transfection efficiency of Exgen 500 polyplexes at their optimal N/P ratio of $5 / 1$ was taken as reference (set at 1.0 ).

with average diameters $\leq 200 \mathrm{~nm}$ and positive surface charge. The polymers possess high buffer capacities in the $\mathrm{pH}$ range 7.4-5.1, a property that may favorably contribute to endosomal escape and therefore to their efficiency as gene delivery vector. The presence of quaternary nicotinamide moieties in the polymer leads to an increased DNA binding capacity, which can be attributed to a combination of electrostatic and intercalating interactions. Polyplexes from $\mathrm{p}(\mathrm{Nic} 30-\mathrm{NHBoc})$ and $\mathrm{p}(\mathrm{Nic} 30-\mathrm{NHAC})$, having $30 \%$ of quaternary nicotinamide groups in their side chains, show much higher transfection than the polyplexes from similar polymers lacking the nicotinamide group, and up to four times higher transfection is observed compared to the reference polymer Exgen500 (linear PEI). Moreover, these polymers display essentially no cytotoxicity, which is an additional advantage compared to PEl. The presence of the Boc-protected amino groups in $\mathrm{p}(\mathrm{Nic} X-\mathrm{NHBoc})$ and the free amino groups in $\mathrm{p}\left(\mathrm{Nic} X-\mathrm{NH}_{2}\right)$ allows further modification of these polymers for in vivo application, which will be part of our future studies.

\section{Experimental Section}

\section{Materials}

$N, N^{\prime}$-cystaminebisacrylamide (CBA, polysciences, USA), tert-butyl-4aminobutylcarbamate (BocNH-BuNH${ }_{2}$, Aldrich), branched polyethylenimine (B-pEl, Mw $25 \mathrm{kDa}$, Aldrich), linear polyethylenimine (Exgen 500, Fermentas, Germany), and heparin (from porcine mucosa, MW 6000-30000, Sigma) were purchased in the highest purity and used without further purification. Ultrafiltration membranes (MWCO 1000) were ordered from Millipore. The plasmid pCMVLacZ, containing a bacterial LacZ gene preceded by a nuclear localization signal under control of a CMV promoter, was purchased from Plasmid Factory (Bielefeld, Germany). 


\section{Synthesis of Nicotinamide-containing monomers}

Nic-BuNHBoc, 1-(4-tert-butoxycarbonylaminobutyl)-3-carbamoylpyridinium, was synthesized as its chloride salt following literature procedures $^{[28]}$ (Scheme 1). In short, to a solution of 3-carbamoyl-1(2,4-dinitrophenyl)pyridinium chloride 1 (1 equiv) in methanol was added tert-butyl-4-aminobutylcarbamate (BocNH-BuNH ${ }_{2}$ ) (3 equiv). The mixture was refluxed for $12 \mathrm{~h}$. After cooling to room temperature, $\mathrm{Et}_{2} \mathrm{O}$ was added and the solvent decantated. The residue was washed three times with acetonitrile. The solvent was decanted to afford Nic-BuNHBoc as a yellow solid. Yield: $46 \%,{ }^{1} \mathrm{H}$ NMR $\left(300 \mathrm{MHz},\left[\mathrm{D}_{6}\right] \mathrm{DMSO}, 25^{\circ} \mathrm{C}, \mathrm{TMS}\right): \delta=9.61\left(\mathrm{~s}, 1 \mathrm{H}, \mathrm{C}_{2} \mathrm{H}\right), 9.23(\mathrm{~d}, J-$ $\left.(\mathrm{H}, \mathrm{H})=6 \mathrm{~Hz}, 1 \mathrm{H}, \mathrm{C}_{4} \mathrm{H}\right), 9.00\left(\mathrm{~d}, J(\mathrm{H}, \mathrm{H})=8 \mathrm{~Hz}, 1 \mathrm{H}, \mathrm{C}_{6} \mathrm{H}\right), 8.76(\mathrm{~s}, 1 \mathrm{H}$, $\left.\mathrm{CONH}_{2}\right), 8.27\left(\mathrm{dd}, J(\mathrm{H}, \mathrm{H})=6\right.$ and $\left.8 \mathrm{~Hz}, 1 \mathrm{H}, \mathrm{C}_{5} \mathrm{H}\right), 8.16(\mathrm{~s}, 1 \mathrm{H}$, $\left.\mathrm{CONH}_{2}\right), 6.87(\mathrm{~s}, 1 \mathrm{H}, \mathrm{NHCO}), 4.67\left(\mathrm{t}, J(\mathrm{H}, \mathrm{H})=7 \mathrm{~Hz}, 2 \mathrm{H}, \mathrm{C}_{7} \mathrm{H}_{2}\right), 2.96$ $\left(\mathrm{d}, J(\mathrm{H}, \mathrm{H})=6 \mathrm{~Hz}, 2 \mathrm{H}, \mathrm{C}_{10} \mathrm{H}_{2}\right), 1.91\left(\mathrm{~m}, 2 \mathrm{H}, \mathrm{C}_{8} \mathrm{H}_{2}\right), 1.42\left(\mathrm{~m}, 2 \mathrm{H}, \mathrm{C}_{9} \mathrm{H}_{2}\right)$, 1.40-1.35 ppm (s, 9H, Boc); ${ }^{13} \mathrm{C}$ NMR $\left(75 \mathrm{MHz},\left[\mathrm{D}_{6}\right] \mathrm{DMSO}, 25^{\circ} \mathrm{C}\right)$ : $\delta=163.5\left(\mathrm{CONH}_{2}\right), 156.4(\mathrm{NHCOO}), 147.0,145.5$ and $144.2\left(\mathrm{C}_{2,4,6}\right)$, 134.5 and $128.5\left(C_{3,5}\right), 78.3\left(C_{11}\right), 61.5\left(C_{7}\right), 40.1\left(C_{10}\right), 28.9$ (Boc), 28.7 $\left(C_{8}\right), 26.6 \mathrm{ppm}\left(\mathrm{C}_{9}\right) ; \quad \mathrm{MS} \quad(\mathrm{FAB}), \mathrm{m} / \mathrm{z} 294.3 \quad\left(\left[\mathrm{M}^{+}\right]\right)$, calc for $\left[\mathrm{C}_{15} \mathrm{H}_{24} \mathrm{~N}_{3} \mathrm{O}_{3}{ }^{+}\right] 294.2$.

Nic-BuNH 2 , 1-(4-aminobutyl)-3-carbamoylpyridinium, was obtained as its triflate salt after deprotection of Nic-BuNHBoc with TFA (3 equivalents) in $\mathrm{MeOH}$. After evaporation of the solvent, the product was obtained as a pale brown solid. Yield $=99 \%,{ }^{1} \mathrm{H}$ NMR (300 MHz, $\left.\mathrm{D}_{2} \mathrm{O}, 25^{\circ} \mathrm{C}, \mathrm{TMS}\right): \delta=9.38\left(\mathrm{~s}, 1 \mathrm{H}, \mathrm{C}_{2} \mathrm{H}\right), 9.08(\mathrm{~d}, J(\mathrm{H}, \mathrm{H})=$ $\left.6 \mathrm{~Hz}, 1 \mathrm{H}, \mathrm{C}_{4} \mathrm{H}\right), 8.94\left(\mathrm{~d}, J(\mathrm{H}, \mathrm{H})=8 \mathrm{~Hz}, 1 \mathrm{H}, \mathrm{C}_{6} \mathrm{H}\right), 8.25(\mathrm{dd}, J(\mathrm{H}, \mathrm{H})=6$ and $\left.8 \mathrm{~Hz}, 1 \mathrm{H}, \mathrm{C}_{5} \mathrm{H}\right), 4.76\left(\mathrm{t}, J(\mathrm{H}, \mathrm{H})=4 \mathrm{~Hz}, 2 \mathrm{H}, \mathrm{C}_{7} \mathrm{H}_{2}\right), 3.10(\mathrm{~d}, J(\mathrm{H}, \mathrm{H})=$ $\left.7 \mathrm{~Hz}, 2 \mathrm{H}, \mathrm{C}_{10} \mathrm{H}_{2}\right), 2.18\left(\mathrm{~m}, 2 \mathrm{H}, \mathrm{C}_{8} \mathrm{H}_{2}\right), 1.81 \mathrm{ppm}\left(\mathrm{m}, 2 \mathrm{H}, \mathrm{C}_{9} \mathrm{H}_{2}\right)$; ${ }^{13} \mathrm{C}$ NMR $\left(75 \mathrm{MHz}, \mathrm{D}_{2} \mathrm{O}, 25^{\circ} \mathrm{C}\right): \delta=165.9\left(\mathrm{CONH}_{2}\right), 146.7,144.6$ and $144.3\left(C_{2,4,6}\right), 134.3$ and $128.7\left(C_{3,5}\right), 61.7\left(C_{7}\right), 38.8\left(C_{10}\right), 27.8\left(C_{8}\right)$, $23.7 \mathrm{ppm}\left(\mathrm{C}_{9}\right)$; $\mathrm{MS}(\mathrm{FAB}), \mathrm{m} / \mathrm{z} 194.2\left(\left[\mathrm{M}^{+}\right]\right)$, calc for $\left[\mathrm{C}_{10} \mathrm{H}_{16} \mathrm{~N}_{3} \mathrm{O}^{+}\right]$ 194.2.

\section{Synthesis of poly(amido amine)s (PAAs)}

Homopolymers: PAA homopolymers can be readily synthesized by Michael addition of the appropriate monoamine compound and CBA in equimolar amounts. ${ }^{[20,23-25]}$ For the synthesis of the $p(\mathrm{Nic0}-$ $\mathrm{NHBoc}$ ) homopolymer (Scheme 2), $1.22 \mathrm{~g}$ of BocNH-BuNH (6.47 mmol, 1 equiv) and $1.69 \mathrm{~g}$ of $\mathrm{CBA}(6.47 \mathrm{mmol}, 1$ equiv) were dissolved in a 4:1 mixture of $\mathrm{MeOH}: \mathrm{H}_{2} \mathrm{O}(3.2 \mathrm{~mL})$ in a brown reaction flask under inert atmosphere. Polymerization was carried out in the dark at $40^{\circ} \mathrm{C}$. The reaction mixture became homogeneous in less than $1 \mathrm{~h}$ and the reaction was allowed to proceed for 5 days yielding a viscous solution. Subsequently, $15 \mathrm{~mol} \%$ excess BocNH$\mathrm{BuNH}_{2}(0.18 \mathrm{~g}, 0.97 \mathrm{mmol})$ was added to consume any unreacted acrylamide groups and stirring was continued for 2 days at $40^{\circ} \mathrm{C}$. The resulting solution was diluted with water to about $30 \mathrm{~mL}$, acidified with $4 \mathrm{M} \mathrm{HCl}$ to $\mathrm{pH} \sim 4$, and then ultrafiltrated through a ultrafiltration membrane (MWCO $1000 \mathrm{~g} \mathrm{~mol}^{-1}$ ) for 1 day. After freeze-drying, the $\mathrm{p}$ (Nic0-NHBoc) homopolymer was collected as the $\mathrm{HCl}$ salt.

Copolymers: PAA copolymers with varying amounts of quaternary nicotinamide moieties were synthesized by reaction of CBA with a mixture of BocNH-BuNH${ }_{2}$ and $\mathrm{Nic}-\mathrm{BuNH}_{2}$ at various ratios (that is, 90/10, 70/30, and 50/50). In a typical experiment, the $p$ (Nic50$\mathrm{NHBoc}$ ) copolymer was synthesized by adding $0.57 \mathrm{~g}$ of $\mathrm{CBA}$ $\left(2.20 \mathrm{mmol}, \quad 1\right.$ equiv), $0.21 \mathrm{~g}$ of ${\text { BocNH}-B_{N N H}}_{2} \quad(1.10 \mathrm{mmol}$, 0.5 equiv), and $0.22 \mathrm{~g}$ of $\mathrm{Nic}^{-\mathrm{BuNH}_{2}}(1.10 \mathrm{mmol}, 0.5$ equiv) into a brown reaction flask with methanol as a solvent $(1.1 \mathrm{~mL})$ and stirring the reaction mixture at $40^{\circ} \mathrm{C}$ in the dark under nitrogen atmosphere. The reaction was allowed to proceed for 5 days, yielding a viscous solution. Subsequently, $15 \mathrm{~mol} \%$ excess of BocNH-
$\mathrm{BuNH}_{2}(0.06 \mathrm{~g}, 0.33 \mathrm{mmol})$ was added to consume any unreacted acrylamide groups and stirring was continued for 2 days at $40^{\circ} \mathrm{C}$. The resulting solution was diluted with water to about $30 \mathrm{~mL}$, acidified with $4 \mathrm{M} \mathrm{HCl}$ to $\mathrm{pH} \sim 4$, and dialyzed through dialysis membrane (MWCO $1000 \mathrm{~g} \mathrm{~mol}^{-1}$ ) for 3 days. After freeze-drying the copolymer was obtained as $\mathrm{HCl}$ salt. In a similar way, the copolymers $\mathrm{p}$ (Nic30-NHBoc) and $\mathrm{p}$ (Nic10-NHBoc) were prepared after reaction of 5 days. The composition of these polymers was established by ${ }^{1} \mathrm{H}$ NMR $\left(\mathrm{D}_{2} \mathrm{O}, 300 \mathrm{MHz}\right)$.

\section{Deprotection and acetylation of PAAs}

The Boc-protecting groups of the side chain of the homopolymer and copolymers $\mathrm{p}$ (Nic $X$-NHBoc) $(X=0 \%$ and 10 or $30 \%$, respectively) were removed using trifluoroacetic acid (TFA) in methanol to obtain the $\mathrm{p}\left(\mathrm{Nic} X-\mathrm{NH}_{2}\right)$ polymers with free terminal amino-groups. In a typical example, $1.00 \mathrm{~g}$ of polymer $(\sim 2.2 \mathrm{mmol}$ of monomer unit, 1 equiv) was dissolved in $5 \mathrm{~mL}$ of $\mathrm{MeOH}$ and $0.5 \mathrm{~mL}$ of TFA ( $6.6 \mathrm{mmol}, 3$ equiv) was added dropwise. The reaction mixture was stirred at room temperature for $6 \mathrm{~h}$. The resulting solution was diluted with water to about $30 \mathrm{~mL}$, acidified with $4 \mathrm{M} \mathrm{HCl}$ to $\mathrm{pH} \sim 4$, and dialyzed through dialysis membrane (MWCO $1000 \mathrm{~g} \mathrm{~mol}^{-1}$ ) for 1 day. After freeze-drying the copolymer was obtained as $\mathrm{HCl}$ salt to avoid undesired reactions. ${ }^{[28]}$

Acetylation of the free amino-groups in the $\mathrm{p}\left(\mathrm{Nic} X-\mathrm{NH}_{2}\right)$ polymers to yield the $\mathrm{p}(\mathrm{Nic} X-\mathrm{NHAc})$ polymers was performed following literature procedures. ${ }^{[37,38]}$ For example, $0.12 \mathrm{~g}$ of polymer $\mathrm{p}\left(\mathrm{Nic} \mathrm{O}-\mathrm{NH}_{2}\right)$ ( $0.34 \mathrm{mmol}, 1$ equiv) were dissolved in $5 \mathrm{~mL}$ of freshly distilled methanol and $0.2 \mathrm{~mL}$ of acetic anhydride ( $1.36 \mathrm{mmol}, 4$ equiv) were added. The reaction mixture was stirred to for $6 \mathrm{~h}$ at $60^{\circ} \mathrm{C}$. The reaction was then quenched with $20 \mathrm{~mL}$ of water, and dialyzed through dialysis membrane (MWCO $1000 \mathrm{~g} \mathrm{~mol}^{-1}$ ) for 1 day. Subsequently, the solution was lyophilized to afford the p(Nic0-NHAc) polymer.

\section{Polymer characterizations}

${ }^{1} \mathrm{H}$ and ${ }^{13} \mathrm{C}$ NMR spectra were recorded on Varian Inova spectrometer operating at $300 \mathrm{MHz}$ and $75 \mathrm{MHz}$, respectively. For ${ }^{13} \mathrm{C} \mathrm{NMR}$ spectra, polymer samples were prepared by dissolving polymer (in salt-free form, about $150 \mathrm{mg}$ ) in $0.7 \mathrm{~mL}$ of $\mathrm{D}_{2} \mathrm{O}$.

Molecular weight $\left(M_{w}\right)$ determination of the $\mathrm{p}(\mathrm{Nic}$-NHBoc) polymers using GPC did not yield reliable results which is probably due to the amphiphatic state of these polymers. Therefore, the Mw was estimated from a combination of light scattering ( 90 and $7^{\circ}$ ), refractive index (RI), and viscosimetry measurements ${ }^{[39]}$ using a TDA302 system (Viscotec, Oss, The Netherlands). A water/methanol mixture $(1 / 4)$ was used as the solvent. This yielded the following data: $\mathrm{p}$ (Nic50-NHBoc), $M_{\mathrm{w}}$ 19.6 $( \pm 2.5) \mathrm{kD} ; \mathrm{p}$ (Nic30-NHBoc), $M_{\mathrm{w}}$ 26.0$( \pm 1.9) \mathrm{kD} ; \mathrm{p}$ (Nic10-NHBoc), $M_{\mathrm{w}}$ 6.3( \pm 0.4$) \mathrm{kD} ; \mathrm{p}$ (Nic0-NHBoc) $M_{\mathrm{w}}>$ $1 \mathrm{kD}$, could not be accurately determined. It should be noted that the $M_{\mathrm{w}}$ values thus obtained are probably underestimated, as this method yields for the commercial B-PEl 25 kid an $M_{w}$ value of $13.1 \mathrm{kD}$.

The buffering capacity of the PAA polymers was determined by acid-base titration. An amount equal to $2.5 \mathrm{mmol}$ of amine groups of the PAA polymer was dissolved in $5 \mathrm{~mL}$ of $150 \mathrm{~mm} \mathrm{NaCl}$ aqueous solution. The $\mathrm{pH}$ of the polymer solution was set at 2.0 and the solution was titrated with $0.1 \mathrm{M} \mathrm{NaOH}$ solution using an automatic titrator (Metrohm 702 SM Titrino). For comparison, branched pEI $\left(M_{\mathrm{w}}=25 \mathrm{kDa}\right)$ dissolved in $150 \mathrm{~mm}$ aqueous solution adjusted to $\mathrm{pH}$ 2.0, was also titrated using the same method. The buffering capacity defined as the percentage of amine groups becoming 
protonated from $\mathrm{pH} 5.1$ to 7.4 , was calculated from equation: Buffer capacity $(\%)=100\left(\Delta V_{\mathrm{NaOH}} \cdot 0.1 \mathrm{M} \mathrm{N}^{-1} \mathrm{~mol}^{-1}\right.$, wherein $\Delta V_{\mathrm{NaOH}}$ is the volume of $\mathrm{NaOH}$ solution $(0.1 \mathrm{M})$ required to bring the $\mathrm{pH}$ value of the polymer solution from 5.1 to 7.4 , and $\mathrm{N}$ mole $(2.5 \mathrm{mmol})$ is the total moles of protonable amine groups in PAA polymer.

\section{Particle size and zeta-potential measurements}

The surface charge and the size of polyplexes were measured at $25^{\circ} \mathrm{C}$ with a Zetasizer 2000 instrument and a Zetasizer 4000, respectively (Malvern Instruments Ltd., Malvern, UK). PAA/plasmid DNA polyplexes at a polymer/DNA mass ratio 12/1 were prepared by adding a HEPES buffer solution ( $20 \mathrm{~mm}, \mathrm{pH} 7.4,5 \mathrm{wt} \%$ glucose) of poly(amido amine)s ( $\left.800 \mu \mathrm{L}, 225 \mu \mathrm{g} \mathrm{mL}^{-1}\right)$ to a HEPES buffer solution $(20 \mathrm{~mm}, \mathrm{pH} 7.4,5 \mathrm{wt} \%$ glucose) of plasmid DNA $(200 \mu \mathrm{L}$, $75 \mu \mathrm{g} \mathrm{mL}^{-1}$ ), followed by vortexing for $5 \mathrm{~s}$ and incubating at room temperature for $30 \mathrm{~min}$. The use of HEPES glucose buffer solution enables the parallel comparison of both zeta-potential and particle size of different PAA polyplexes in the same samples. HEPES glucose buffer solution is also used to prepare polyplex samples for the in vitro transfection experiments. It should be noted, however, that the zeta-potentials of polyplexes in HEPES saline buffer solution are generally lower than those measured in HEPES glucose buffer solution, due to surface shielding effects of a higher counter ion concentration.

\section{Fluorescence measurements}

To asses whether the quaternary nicotinamide moieties have a positive interaction with the pDNA, free DNA was detected by fluorescence with ethidium bromide that was added to a DNA solution $\left(75 \mu \mathrm{g} \mathrm{mL}^{-1}\right)$ in a $1: 10$ molar ratio to the DNA phosphates. ${ }^{[00]} \mathrm{A}$ solution of the different polymers $\left(800 \mu \mathrm{L}, 0.9 \mathrm{mg} \mathrm{mL}^{-1}\right.$ in HBS) was added to $200 \mu \mathrm{L}$ of DNA, vortexed for $5 \mathrm{~s}$, and incubated for 30 min. Similarly, a $48 / 1$ mass ratio of Nic-BuNHBoc was added to the solution of DNA. The fluorescence of these dispersions was measured before and after the addition of heparin solution (7.5 mL, $\left.2 \mathrm{mg} \mathrm{mL}^{-1}\right) .^{[41]}$ The fluorescence was measured using an Edinburgh FS900 spectrofluorometer. The excitation and emission wavelength were 520 and $600 \mathrm{~nm}$, respectively. The relative fluorescence $\left(F_{r}\right)$ values were determined from the equation: $F_{r}=$ $\left(F_{\text {obs }}-F_{\mathrm{e}}\right) /\left(F_{0}-F_{\mathrm{e}}\right)$, where $F_{\text {obs }}$ is the fluorescence of the polyplex dispersion (before or after the addition of heparin solution), $F_{\mathrm{e}}$ is the fluorescence of ethidium bromide in the absence of DNA, and $F_{0}$ is the initial fluorescence of DNA/ethidium bromide in the absence of polymer.

\section{In vitro transfection and cell viability assays}

Transfection experiments were performed with COS-7 cells (SV-40 transformed African Green monkey kidney cells) by using the plasmid pCMV-LacZ as reporter gene as reported previously. ${ }^{[0,41]}$ Two parallel transfection series, one for the determination of reporter gene expression ( $\beta$-galactosidase) and the other for the evaluation of cell viability by XTT assay, were carried out in separate 96-well plates (approximately $1.0 \times 10^{4}$ cells per well). Different polymer/ plasmid DNA weight ratios, ranging from $3 / 1$ to $12 / 1(w / w)$, were used to prepare the polyplexes. In brief, polyplexes were prepared by adding $200 \mu \mathrm{L}$ of a HEPES buffer solution $(20 \mathrm{~mm}, 130 \mathrm{~mm} \mathrm{NaCl}$, $\mathrm{pH}$ 7.4) of poly(amido amine) with varying concentrations (from 37.5 to $150 \mu \mathrm{g} \mathrm{mL}^{-1}$ ) to $50 \mu \mathrm{L}$ of a HEPES buffer solution (20 mM,
$130 \mathrm{~mm} \mathrm{NaCl}, \mathrm{pH} 7.4)$ of plasmid DNA $\left(50 \mu \mathrm{gL}^{-1}\right)$, followed by gentle shaking and incubating at room temperature for $30 \mathrm{~min}$. All transfection and toxicity assays were carried out in triplicate. In a standard transfection experiment, the cells were incubated with the desired amount of polyplexes $(100 \mu \mathrm{L}$ dispersion with $1 \mu \mathrm{g}$ plasmid DNA per well) for $1 \mathrm{~h}$ at $37^{\circ} \mathrm{C}$ in a humidified $5 \% \mathrm{CO}_{2}$-containing atmosphere. Next, the polyplexes were removed. $100 \mu \mathrm{L}$ of fresh culture medium was added and the cells were cultured for 2 days. The transfection efficiency was determined by measuring the activity of $\beta$-galactosidase using the ONPG assay. ${ }^{[42,43]}$ Exgen 500 at $5 \mathrm{~N} / \mathrm{P}$ ratio was used as a reference. ${ }^{[35]}$ The number of viable cells was measured using an XTT assay. ${ }^{[44]}$ The XTT value for untreated cells (that is, cells not exposed to the transfection medium) was taken as $100 \%$ cell viability.

Keywords: DNA intercalation - gene delivery $\cdot$ poly(amido amine) $\cdot$ polyplex $\cdot$ quaternary nicotinamide

[1] A. El-Aneed, Eur. J. Pharmacol. 2004, 498, 1-8.

[2] A. El-Aneed, J. Controlled Release 2004, 94, 1-14.

[3] U. Griesenbach, D. M. Geddes, E. Alton, Gene Ther. 2006, 13, 1061-1067.

[4] S. R. Little, R. Langer, Adv. Biochem. Eng./Biotechnol. 2005, 99, 93-118.

[5] N. A. Kootstra, I. M. Verma, Annu. Rev. Pharmacol. Toxicol. 2003, 43, 413439.

[6] H. C. Kang, M. Lee, Y. H. Bae, Crit. Rev. Eukaryotic Gene Expression 2005, 15, 317-342.

[7] N. M. Rao, V. Gopal, Expert Opin. Ther. Pat. 2006, 16, 825-844.

[8] F. D. Ledley, Hum. Gene Ther. 1995, 6, 1129-1144.

[9] D. W. Pack, A. S. Hoffman, S. Pun, P. S. Stayton, Nat. Rev. Drug Discovery 2005, 4, 581-593.

[10] M. Thomas, A. M. Klibanov, Appl. Microbiol. Biotechnol. 2003, 62, 27-34.

[11] C. Dufes, I. F. Uchegbu, A. G. Schatzlein, Adv. Drug Delivery Rev. 2005, 57, 2177-2202.

[12] T. G. Park, J. H. Jeong, S. W. Kim, Adv. Drug Delivery Rev. 2006, 58, 467486.

[13] T. Merdan, J. Kopecek, T. Kissel, Adv. Drug Delivery Rev. 2002, 54, 715758.

[14] C. M. Wiethoff, C. R. Middaugh, J. Pharm. Sci. 2003, 92, 203-217.

[15] M. Ruponen, P. Honkakoski, S. Ronkko, J. Pelkonen, M. Tammi, A. Urtti, J. Controlled Release 2003, 93, 213-217.

[16] E. Wagner, Pharm. Res. 2004, 21, 8-14.

[17] D. M. Lynn, R. Langer, J. Am. Chem. Soc. 2000, 122, 10761-10768.

[18] G. T. Zugates, S. R. Little, D. G. Anderson, R. Langer, Isr. J. Chem. 2005, 45, 477-485.

[19] Z. Y. Zhong, Y. Song, J. F. J. Engbersen, M. C. Lok, W. E. Hennink, J. Feijen, J. Controlled Release 2005, 109, 317-329.

[20] E. Emilitri, E. Ranucci, P. Ferruti, J. Polym. Sci. Part A 2005, 43, 14041416.

[21] P. Ferruti, M. A. Marchisio, R. Barbucci, Polymer 1985, 26, 1336-1348.

[22] S. C. W. Richardson, N. G. Pattrick, Y. K. S. Man, P. Ferruti, R. Duncan, Biomacromolecules 2001, 2, 1023-1028.

[23] C. Lin, Z. Y. Zhong, M. C. Lok, X. L. Jiang, W. E. Hennink, J. Feijen, J. F. J. Engbersen, J. Controlled Release 2006, 116, 130-137.

[24] C. Lin, Z. Y. Zhong, M. C. Lok, X. L. Jiang, W. E. Hennink, J. Feijen, J. F. J. Engbersen, Bioconjugate Chem. 2007, 18, 138-145.

[25] . Lin, Z. Y. Zhong, M. C. Lok, X. L. Jiang, W. E. Hennink, J. Feijen, J. F. J. Engbersen, J. Controlled Release 2007, 123, 67-75.

[26] L. V. Christensen, C. W. Chang, W. J. Kim, S. W. Kim, Z. Y. Zhong, C. Lin, J. F. J. Engbersen, J. Feijen, Bioconjugate Chem. 2006, 17, 1233-1240.

[27] J. H. Jeong, L. V. Christensen, J. W. Yockman, Z. Y. Zhong, J. F. J. Engbersen, W. J. Kim, J. Feijen, S. W. Kim, Biomaterials 2007, 28, 1912-1917.

[28] J. F. J. Engbersen, A. Koudijs, H. C. van der Plas, J. Org. Chem. 1990, 55, 3647-3654.

[29] D. G. Anderson, A. Akinc, N. Hossain, R. Langer, Mol. Ther. 2005, 11, 426-434.

[30] O. Boussif, F. Lezouach, M. A. Zanta, M. D. Mergny, D. Scherman, B. Demeneix, J. P. Behr, Proc. Natl. Acad. Sci. USA 1995, 92, 7297-7301.

[31] O. Boussif, M. A. Zanta, J. P. Behr, Gene Ther. 1996, 3, 1074-1080. 
[32] K. Kunath, A.von Harpe, D. Fischer, H. Peterson, U. Bickel, K. Voigt, T. Kissel, J. Controlled Release 2003, 89, 113-125.

[33] R. Kircheis, S. Schuller, S. Brunner, M. Ogris, K. H. Heider, W. Zauner, E. Wagner, J. Gene Med. 1999, 1, 111-120.

[34] M. Neu, O. Germershaus, S. Mao, K. H. Voigt, M. Behe, T. Kissel, J. Controlled Release 2007, 118, 370-380.

[35] W. T. Godbey, K. K. Wu, A. G. Mikos, J. Controlled Release 1999, 60, 149160.

[36] S. Audouy, G. Molema, L. de Leij, D. Hoekstra, J. Gene Med. 2000, 2, 465-476.

[37] M. L. Forrest, G. E. Meister, J. T. Koerber, D. W. Pack, Pharm. Res. 2004 21, 365-371.

[38] M. L. Forrest, N. Gabrielson, D. W. Pack, Mol. Ther. 2004, 9, S138.

[39] S. Ross, Am. Lab. 1999, 31, 30.
[40] A. M. Funhoff, C. F. van Nostrum, M. C. Lok, M. M. Fretz, D. J. A. Crommelin, W. E. Hennink, Bioconjugate Chem. 2004, 15, 1212-1220.

[41] Y. Liu, T. Reineke, Bioconjugate Chem. 2007, 18, 19-30.

[42] J. Y. Cherng, P. van de Wetering, H. Talsma, D. J. A. Crommelin, W. E. Hennink, Pharm. Res. 1996, 13, 1038-1042.

[43] C. Arigita, N. J. Zuidam, D. J. A. Crommelin, W. E. Hennink, Pharm. Res. 1999, 16, 1534-1541.

[44] D. A. Scudiero, R. H. Shoemaker, K. D. Paull, A. Monks, S. Tierney, T. H. Nofziger, M. J. Currens, D. Seniff, M. R. Boyd, Cancer Res. 1988, 48, 48274833.

Received: October 4, 2007

Revised: October 28, 2007

Published online on December 5, 2007 